\title{
VETERANOS Y PRENSA SATÍRICA: DESMOVILIZADOS E INVÁLIDOS EN LOS PERIÓDICOS CHILENOS DE CARICATURAS DURANTE LA GUERRA DEL PACÍFICO (1879-1884)
}

\author{
Veterans and satiric press: Demobilized and disables in Chilean \\ cartoon newspapers during War of the Pacific (1879-1884)
}

Patricio Ibarra*

\section{RESUMEN}

En sus caricaturas, artículos y versos la prensa de sátira chilena contemporánea a la Guerra del Pacífico (1879-1884), acogió como suyos los reclamos de los veteranos tras servir en el Ejército. Allí desplegaron un discurso retórico y visual, para colocar esta temática en la esfera de debate público, refiriéndose a problemas como cesantía, compensaciones impagas o las mutilaciones físicas sufridas por los excombatientes.

Palabras clave: Guerra del Pacífico, prensa satírica, caricaturas chilenas, veteranos de guerra.

\begin{abstract}
In those cartoons, articles and verses the chilean satiric press contemporary to the War of the Pacific (1879-1884), take in war veteran's complains by obtain better life conditions after serve in army. There spread a rhetorical and visual discourse, to put this theme in public debate sphere, about problems like unemployment, unpaid compensations or physic mutilations suffered by veterans.
\end{abstract}

Keywords: War of the Pacific, satiric press, Chilean cartoons, war veterans.

\footnotetext{
* Centro de Estudios Históricos, Dirección de Investigación y Relaciones Internacionales, Universidad Bernardo O’Higgins. Santiago, Chile. Correo electrónico: patricio.ibarra@ubo.cl
}

Artículo recibido el 22 de enero de 2013. Aceptado el 6 de abril de 2013 


\section{INTRODUCCIÓN}

La Guerra del Pacífico, conflicto que enfrentó a Chile con la alianza formada por Perú y Bolivia entre 1879 y 1884, excedió por mucho a la confrontación de tres estados nacionales que defendieron a través de las armas sus intereses en los territorios salitreros de Antofagasta y Tarapacá. El enfrentamiento trajo aparejado, para vencedores y vencidos, consecuencias en el ámbito político, económico, cultural y social.

Los veteranos, como son conocidos los supervivientes de un conflicto armado, debieron soportar la instrucción necesaria para convertirse en hombres de armas, luego la campańa militar en cuanto tal y a la vuelta a su terruńo intentaron retomar sus vidas luego de partir al frente a defender los intereses de sus respectivos países. En el caso de los chilenos, muchos se encontraron con un trabajo mal remunerado e incluso sin él. Otros, debieron enfrentar las consecuencias de las heridas recibidas: cicatrices, dolencias crónicas o, en el peor de los casos, la mutilación de su cuerpo materializada en la pérdida de uno de sus miembros. También, a no pocos se les adeudaban dineros por su servicio en el ejército, sumándose a ello largas tramitaciones para hacer efectivo el pago de la recompensa pecuniaria por parte del Estado, merced a su participación en la guerra.

Desde su tribuna, los editores de periódicos recogieron estas situaciones, uniéndose a los veteranos y sus familias en sus peticiones y reclamos al gobierno, incluyéndolas en los temas debatidos en la opinión pública. ${ }^{2}$

\footnotetext{
${ }^{2}$ Pese a tratarse de un concepto de difícil definición, la opinión pública podría entenderse como el fenómeno social, donde a través de los medios de comunicación se construye un espacio público de intercambio y discusión de ideas, practicándose una crítica constante a las fuerzas políticas en pugna, las instituciones de la Sociedad Civil, los organismos de gobierno y poder del Estado. Según Irving Crespi, la conformación de la opinión pública se trata de un proceso interactivo y multidimensional, donde las posturas de los individuos se forman y cambian, en que las apreciaciones de las personas se transforman en una fuerza colectiva que se pronuncia en términos comunes, la cual es integrada en la conducción de los asuntos del Estado. Así, individuo y grupo actúan en conjunto en "un flujo interminable que va continuamente de las posturas individuales a las coaliciones de opiniones y viceversa." De ese modo, expresiones tales como "la opinión pública ha hablado", o el "juicio del tribunal de la opinión" no son otra cosa que metáforas periodísticas íntimamente ligadas al ideal liberal ilustrado que supone la existencia de un debate informado y racional, pues no se trata que el cuerpo social haya alcanzado un acuerdo en los temas en debate, sino que se ha producido un nuevo equilibrio de poder político al respecto. Carmen Mc Evoy sostiene que durante los años de la guerra, los editores de los periódicos "definieron lo público como instancia de socialización y mediación de lo individual y al mismo tiempo confeccionaron un mapa cognitivo de la guerra que Chile enfrentaba con sus vecinos". Asimismo, la prensa actuó como "centro de noticias, organizadora de múltiples rituales patrióticos, integradora de valores divergentes, tribuna del pueblo, una veces consejera y otra crítica del gobierno, además de núcleo de una retórica republicano-nacionalista". Crespi, Irving. El proceso de opinión pública. Cómo habla la gente. Barcelona: Ariel, (1997): 27-120; Pardos-Prado, Sergi. “¿Qué es y cómo se crea la opinión pública?”. En Eva Anduiza (coord.). Opinión pública y medioambiente. Monografias de educación ambiental. Barcelona: SBEA, SCEA, (2006): 39-40; González Bernaldo de Quirós, Pilar. "Literatura injuriosa y opinión pública en Santiago de Chile durante la primera mitad del siglo XIX”, Estudios Públicos 76, primavera, (1999): 235 y Mc Evoy, Carmen. Guerreros civilizadores. Política, sociedad y cultura en Chile durante la Guerra del Pacifico. Santiago de Chile: Ediciones Universidad Diego Portales, (2011): 138-139.
} 
La estrategia periodística respecto de combatientes y veteranos fue coherente. Durante la primera etapa de la guerra, ensalzó la actuación del roto, representante del bajo pueblo, en los campos de batalla. ${ }^{3}$ Una vez que estos volvieron del norte, exigieron una retribución acorde su participación en la campańa. De este modo, incorporaron la problemática de los veteranos en el espacio de discusión de la esfera pública, cuestionando el actuar de las autoridades de gobierno y la política oficial respecto de los excombatientes. Esto comenzó a poco de la llegada de los primeros soldados licenciados durante la guerra y se mantuvo hasta años después de terminado el conflicto. ${ }^{4}$ La prensa de humor político también participó de las denuncias y solicitudes de veteranos y sus familias, incluyendo en sus ediciones artículos, versos y caricaturas donde señaló las penurias sufridas por los veteranos. Además, la editada por Juan Rafael Allende que, en concordancia con el resto de su obra, mezcló la causa de los excombatientes con la "agenda liberal" del último cuarto del siglo XIX, vale decir, la lucha por la secularización del Estado, la libertad electoral, la defensa de los derechos del bajo pueblo y de los incipientes grupos medios, entre otras. ${ }^{5}$

En las páginas que vienen a continuación, se revisará cómo estos rotativos recogieron e hicieron propia la lucha por reconocimiento y recompensas para los excombatientes. Este trabajo tiene por objeto principal describir y analizar el discurso y

\footnotetext{
${ }^{3}$ Gabriel Cid explora en la creación del roto como referente para el ideario nacionalista chileno de fines del siglo XIX en "Un icono funcional: la invención del roto como símbolo nacional. 1870-1888". En Gabriel Cid y Alejandro San Francisco (eds.). Nación y nacionalismo en Chile. Siglo XIX. Vol. I. Santiago de Chile: Centro de Estudios Bicentenario, (2009): 221-154. Un análisis de la prensa escrita chilena durante los años de la guerra en Rubilar, Mauricio. "Escritos por chilenos, para los chilenos y contra los peruanos: la prensa y el periodismo durante la Guerra del Pacífico (1879-1883)". En Carlos Donoso y Gonzalo Serrano (eds.). Chile y la Guerra del Pacífico. Santiago de Chile: Centro de Estudios Bicentenario, 2010.

${ }^{4}$ Los problemas sufridos por los veteranos chilenos de la Guerra del Pacífico: cesantía, recompensas impagas y la necesidad de aparatos ortopédicos para quienes resultaron mutilados, han sido estudiados en varias monografías específicas. Allí se mencionan las instituciones en que se agruparon y como el gobierno chileno se hizo cargo de sus reclamos. Véase, Rodríguez, Sergio. Problemática del soldado durante la Guerra del Pacífico. Santiago de Chile: Estado Mayor General del Ejército, 1985; el artículo de Donoso, Carlos y Couyoumdjian, Juan. "De soldado orgulloso a veterano indigente. La Guerra del Pacífico". En Rafael Sagredo y Cristián Gazmuri (eds.). Historia de la vida privada en Chile. Tomo II. Santiago de Chile: Taurus, (2006): 237-273. Los trabajos más completos al respecto son Méndez, Carlos. Héroes del silencio. Los veteranos de la Guerra del Pacifico (1884-1924). Santiago de Chile: Centro de Estudios Bicentenario, 2004 y del mismo autor Desierto de esperanzas. De la gloria al abandono. Los veteranos chilenos y peruanos de la guerra del 79. Santiago de Chile: Centro de Estudios Bicentenario, 2009. Recientemente el propio Méndez dio a la luz un nuevo estudio, donde analiza lo acaecido con los veteranos bolivianos. Méndez, Carlos. Dolor y olvido. Los excombatientes bolivianos en la Guerra del Pacífico. Santiago de Chile: Centro de Estudios Bicentenario, 2013.

${ }^{5}$ La obra de Juan Rafael Allende puede ser estudiada en los trabajos de Maximiliano Salinas y otros. Véase, El que ríe último... caricaturas y poesías en la prensa bumorística cbilena del siglo XIX. Santiago de Chile: Centro de Investigaciones Diego Barros Arana, 2011; en la del propio Salinas, "Erotismo, humor y trasgresión en la obra satírica de Juan Rafael Allende", Mapocho 57, primer semestre, 2005 y en la de Cornejo, José Tomás. "La República como mujer en los periódicos de Juan Rafael Allende: Un discurso político en caricaturas", Mapocho 59, 2006.
} 
retórica en clave satírica, desplegada en sus ejemplares explorando, a través de ellas, en la visión de los editores de esos periódicos y dibujantes respecto de la situación en que se encontraban los veteranos. Para ello, se utilizarán los artículos, versos y caricaturas publicadas en los periódicos Diógenes, El Corvo y El José Peluca. Además, de los editados por Juan Rafael Allende: El Ferrocarrilito, El Padre Cobos y El Padre Padilla. ${ }^{6}$ Allí, se puso de manifiesto a la opinión pública de la época la situación en que se encontraron muchos de los soldados que hicieron la campaña al Perú y Bolivia, a su vuelta a Chile, tanto los que resultaron ilesos y, especialmente, quienes quedaron mutilados producto de las heridas recibidas en combate u otras en tareas de índole militar.

Así, conocer lo expuesto en la prensa chilena de humor a propósito del problema específico de los veteranos de guerra, da cuenta de una de las formas de deliberación y debate producidos en la esfera pública chilena decimonónica mientras en paralelo se desarrollaba un enfrentamiento armado contra dos naciones al unísono, donde fueron utilizados todos los recursos discursivos, retóricos y gráficos disponibles, aprovechando el formato y características de la sátira, además del espacio de tolerancia temática y de contenidos otorgado por la libertad de prensa consagrada en la ley de 1872. Al mismo tiempo, permite señalar como los escritos e imágenes presentadas en los periódicos de caricaturas a propósito de las vicisitudes de los excombatientes, sirvieron de vehículo para exigir recompensas y reparaciones por los servicios prestados al Estado, por ciudadanos transformados en soldados producto del estallido de la guerra, mostrándolos además como símbolo del esfuerzo patriótico del roto, de la inoperancia y desdén de los gobiernos de Aníbal Pinto y Domingo Santa María ante los problemas del país, del predominio de los intereses de la oligarquía por sobre los del pueblo, así como de las consecuencias de la guerra materializadas en individuos concretos; todo ello en el marco de las ideas y valores colectivos correspondientes del último cuarto del siglo XIX, periodo clave en la

\footnotetext{
${ }^{6}$ El método utilizado para analizar las caricaturas presentadas en este escrito, está basado en los planteamientos de los miembros de la Escuela de Warburg durante la primera mitad del siglo XX, además de algunas de las propuestas del historiador británico Peter Burke expresadas en su libro Visto y no visto. El uso de la imagen como documento histórico. Barcelona: Crítica, 2001. En síntesis, se trata de la descripción de las imágenes (iconografía), como lo sugirió Edwin Panofsky en 1939, distinguiendo tres niveles de significado en cada obra. El primero de ellos está relacionado con la denominada "descripción preiconográfica", referida al "significado natural" de los elementos incluidos en una caricatura, es decir, identificar los objetos (personas, armas, emblemas, etc.) y situaciones (batallas, reuniones, conversaciones, etc.). El nivel siguiente trata del estudio iconográfico en sentido estricto, entregando el "significado convencional" de las imágenes, donde se identifica y define el acontecimiento al que se refiere el dibujo para no confundirlo con otro. Finalmente se procede a interpretación iconológica, donde cada grabado fue colocado en su contexto histórico y material, en búsqueda de su significado y de la orientación intrínseca del testimonio visual referida al fenómeno estudiado. Burke, Peter. Visto y no visto. El uso de la imagen como documento histórico. Barcelona: Crítica, (2001): 44-45 y 239-240.
} 
consolidación del Estado Nacional y el sistema republicano, tanto por la expansión territorial como también el afianzamiento de la identidad moderna de los chilenos. ${ }^{7}$

\section{LA PROBLEMÁTICA DE LOS VETERANOS DE LA GUERRA DEL PACÍFICO Y SU REVERSO SATÍRICO}

Los artículos, versos y caricaturas publicados en los periódicos satíricos chilenos durante la Guerra del Pacífico, señalaron y fijaron el punto de vista de sus creadores respecto de las distintas alternativas del conflicto. Así, como parte del tribunal de la opinión, participaron del debate producido en Chile a propósito del estallido, desarrollo y consecuencias del conflicto de 1879, librándose duras batallas y combates, donde se esgrimió la palabra, la pluma y la tinta.

No obstante, la guerra no monopolizó la temática de sus escritos o grabados pues nunca dejaron de referirse a las luchas partidistas de la época, así fuera la intervención electoral propiciada desde el poder ejecutivo o la lucha por secularización del Estado, entre otros temas significativos del período. ${ }^{8}$

En artículos y versos los editores de los periódicos satíricos señalaron su perspectiva respecto de la contingencia desde el formato escrito. A ello se suman las caricaturas, que desde su aparición se constituyeron como un eficaz medio de difusión de puntos de vista y de tentativa por influir en la opinión pública. Cada dibujo implica una reflexión aguda respecto del acontecer de la sociedad, pues

\footnotetext{
${ }^{7}$ Los La obra de Carmen Mc Evoy, Guerreros civilizadores, ya citada, permite reconocer el profundo impacto y trascendencia del conflicto en la Sociedad Civil en el plano emocional, discursivo, simbólico y cultural, a partir de la retórica y discurso nacionalista desplegado por las autoridades, instituciones y prensa contemporáneas, que ha dejado una huella indeleble en la memoria histórica de los chilenos, más allá de si efectivamente Chile llevó adelante una "cruzada civilizadora" que legitimó el uso de la fuerza, como lo propone la historiadora peruana en su obra. En ese mismo sentido, debe tenerse en cuenta lo afirmado por William Sater en Chile and the War of the Pacific, quien, al analizar la vida cotidiana del "frente interno" durante el conflicto a partir del análisis de un gran volumen de periódicos y documentación de archivo, afirma que la Guerra del Pacífico no cambió dramáticamente la sociedad chilena a nivel político, pues no se involucró en una "guerra total"; en tanto no se modificó el sistema económico, los aliados nunca amagaron su territorio, no hubo carestía de alimentos y, sobre todo, la estructura social no se modificó sustancialmente. Sater, William. Chile and the War of the Pacific. Lincoln: University of Nebraska Press, (1986): 177.

${ }^{8}$ Isabel Cruz de Amenábar y Trinidad Zaldívar en su artículo "El trazado fronterizo de la caricatura. Confrontación y cohesión en el proceso limítrofe chileno 1879-1902", estudian algunas caricaturas publicadas durante el periodo de la guerra desde la perspectiva de la presentación lúdica de los hechos, recurriendo a la ironía y la parodia transformado el conflicto en "juego de niños", por parte de editores de periódicos y dibujantes haciendo la información asequible a la "mayoría del país". Cruz de Amenábar y Zaldívar, Trinidad. "El trazado fronterizo de la caricatura. Confrontación y cohesión en el proceso limítrofe chileno 1879-1902”, Boletín de la Academia Cbilena de la Historia 106 (1996):122-158.
} 
enseña al observador de la obra, la posición y percepción del autor respecto de los hechos, generalmente relacionados con la contingencia política. En esencia, los rotativos de humor político eran una prensa militante y de batalla, pues podían abanderizarse a favor o en contra de personas, instituciones o ideologías. ${ }^{9}$ En general, desde su irrupción en 1858 con El Correo Literario, los periódicos chilenos de caricaturas adscribieron a los ideales y valores de la modernidad política decimonónica, materializada en el liberalismo republicano, a su vez influenciado por las ideas de las revoluciones francesa de 1830 y 1848 , donde se incorporó lenta pero inexorablemente al pueblo, en el lenguaje y simbolismo de la disputa política. Hacia mediados de la década de 1870, yespecialmentela de 1880, su lenguajevisual yescrito se tornó cada vez más acre y desenfadado, al atacar a las personas e instituciones. ${ }^{10}$

Pese a las masivas manifestaciones populares registradas a la llegada de las tropas desde el norte, especialmente tras la toma de Lima, muchos de los soldados desmovilizados pasaron por diversas vicisitudes para reinsertarse en la sociedad chilena. La prensa de sátira recogió aquella problemática y materializó su visión al respecto en columnas de opinión, caricaturas y versos, inspirados en esos individuos y sus familias, haciéndose parte y visibilizando en la esfera de discusión pública esas reivindicaciones.

Como ya se mencionó en líneas precedentes, uno de los inconvenientes para los veteranos que resultaron ilesos en la campaña, fue que tras volver a Chile accedieron a empleos mal remunerados, inestables o bien permanecieron largo tiempo cesantes. Además, la demora en los pagos correspondientes a sus sueldos por los servicios prestados en el Ejército fue una constante. Empero, gracias a la promulgación de leyes especiales, los excombatientes pudieron acceder a exiguas pensiones, que en la mayoría de los casos sólo alcanzaban para el sustento básico. ${ }^{11}$ Estas y otras situaciones, motivaron la aparición de asociaciones y mutuales organizadas por los propios veteranos, cuyo objetivo era articular su acción común,

\footnotetext{
9 Guerrero, Cristián. "Los capitanes de la industria a través de las caricaturas contemporáneas, 1870-1920", Cuadernos de Historia 16 (1996): 1.

${ }^{10}$ Zaldívar, Trinidad. "El papel de los monos. Breve crónica de un tercio de siglo de prensa de caricatura 1858 - 1891". En Ángel Soto (ed.). Entre tintas y plumas: historias de la prensa cbilena del Siglo XIX. Santiago de Chile: Universidad de los Andes, Centro de Investigación de Medios Andes, CIMA, Facultad de Comunicación, (2004): 140-145.

${ }^{11}$ Méndez, Carlos. Héroes del silencio..., 30.
} 
en pos de conseguir una pronta solución para sus padecimientos. ${ }^{12}$

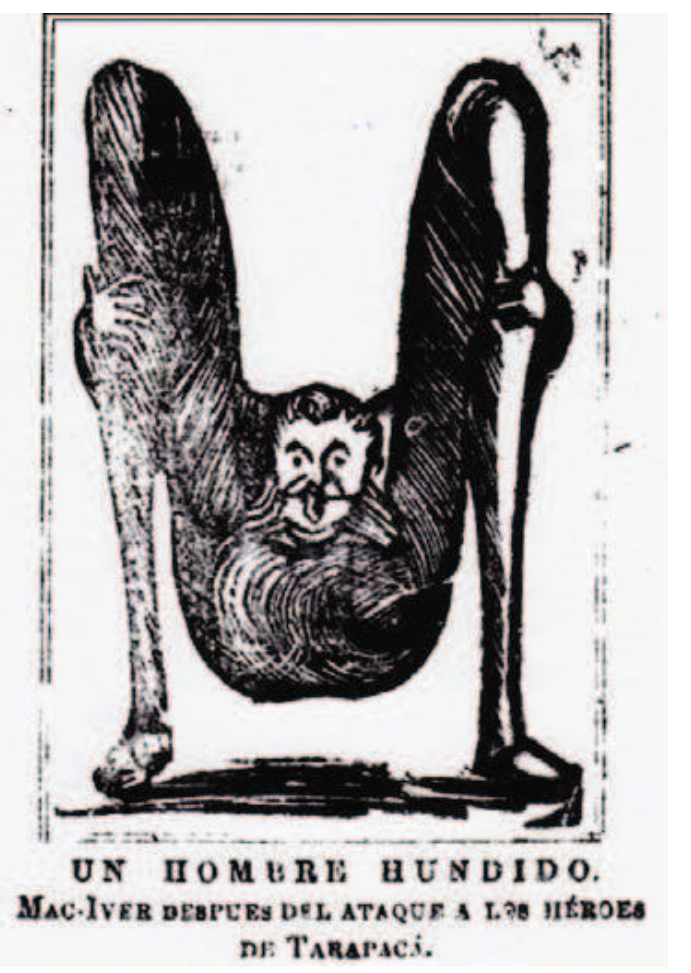

Figura 1

La discusión respecto de cuál debía ser la recompensa apropiada para los ex combatientes, y especialmente para quienes habían resultado heridos de gravedad y amputados alguno de sus miembros, se inició en el Congreso hacia 1880 y se materializó en una ley a fines de 1881. Una de las controversias al respecto, fue si esta consideraría a todos los efectivos movilizados durante la guerra o sólo a aquellos que resultaron heridos o inválidos. Otra arista de la discusión se encontró en cómo establecer criterios uniformes de calificación respecto del nivel de incapacidad, total o parcial, de cada soldado dado de baja por problemas físicos, con el objeto de asignar el pago correspondiente a uno de ellos. ${ }^{13}$

\footnotetext{
${ }^{12}$ Es el caso del "Círculo de Veteranos del 79", la "Sociedad de Defensores de Chile", el "Círculo de Jefes y Oficiales del Ejército y la Marina" y la "Liga Patriótica Militar". Por su parte, el Estado chileno creo algunas instituciones para apoyar a las viudas y huérfanos de la guerra. Entre ellas se cuentan la "Escuela agrícola de Agua Negra", "Escuela agrícola para hijos huérfanos de la guerra" y "Sociedad protectora de viudas y huérfanos de los mártires de la Patria" (Sociedad Protectora de Valparaíso). A ellos se debe agregar el "Asilo de la Patria" establecimiento creado por la Iglesia católica, aunque recibía financiamiento fiscal, el cual se ocupaba de dar alojamiento, alimentación y educación a hijos de soldados fallecidos durante el conflicto. Ibíd., 44-54. Home, David. Los huérfanos de la Guerra del Pacífico: El 'Asilo de la Patria', 1879-1885. Santiago de Chile: Centro de Investigaciones Diego Barros Arana de la Dirección de Bibliotecas, Archivos y Museos y LOM Ediciones, 2006.

${ }^{13}$ Méndez, Carlos. Héroes del silencio..., 57.
} 
En ese contexto, el primer periódico que se abanderó junto a los veteranos fue El Ferrocarrilito, editado por Juan Rafael Allende. El rotativo recogió lo ocurrido en la sesión de la Cámara de Diputados del 30 de julio de 1880, donde el representante por Talca Enrique Mac Iver, señaló que recompensas y medallas debían ser entregadas sólo a quienes participaron en las victorias chilenas, y no de las derrotas, como a su juicio fue el caso de la batalla de Tarapacá, donde las tropas chilenas sufrieron un revés ante el ejército peruano replegado tras la batalla de Dolores. Las declaraciones de Mac Iver, junto con la polémica desatada en la propia sala, significaron ganarse la malquerencia del periódico, que el 14 de agosto de 1880 publicó una caricatura donde se le muestra como un hombre hundido y repudiado tras su "ataque a los Héroes de Tarapacá" (Figura 1). ${ }^{14}$

$\mathrm{Al}$ año siguiente, El Corvo hizo notar los problemas que comenzaban a tener los veteranos que ya habían regresado a Chile. En marzo de 1881, a dos meses de la conquista de Lima y faltando pocos días para la vuelta del grueso del Ejército Expedicionario del Norte, publicó una serie artículos y grabados donde hizo hincapié en los malos tratos sufridos por los soldados, así como en los inconvenientes para encontrar un empleo. ${ }^{15}$ Una de esas caricaturas muestra a un hombre que trabaja como peón agrícola luego de ser desmovilizado del Ejército. La leyenda que acompańa el grabado, lo muestra quejándose de sus bajos ingresos, pese a haber servido y librado sin rasguño en la campaña que acababa de terminar (Figura 2). ${ }^{16}$ En otra caricatura, El Corvo se hizo cargo de los apuros económicos en que se encontraron quienes resultaron inválidos de por vida. La ilustración muestra a un soldado, quien perdió su pie izquierdo y por ello apoyado en una muleta, implorando y recibiendo limosna de una mujer en la entrada de una casa. Fue publicado el 12 de marzo de 1881, al día siguiente de la llegada del general Manuel Baquedano a Valparaíso con parte de la parte de las tropas que tomaron Lima (Figura 3). ${ }^{17}$

\footnotetext{
${ }^{14}$ El Ferrocarrilito, Santiago, agosto 14 de 1880.

15 "Destripaduras", En: El Corvo, Santiago, marzo 5 de 1881.

${ }^{16}$ Idem.

${ }^{17}$ Idem.
} 

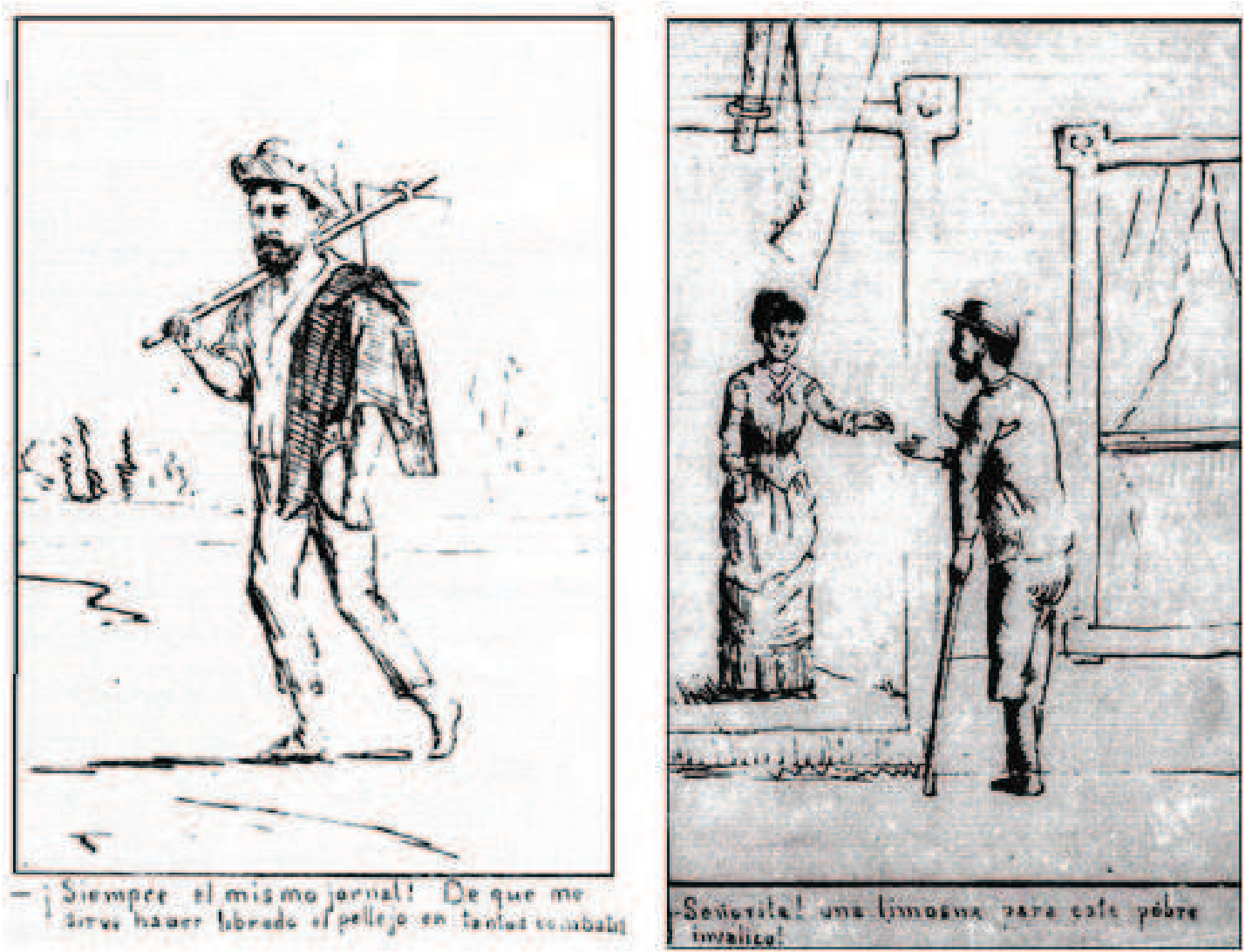

Figuras 2 y 3

El Corvo se caracterizó por sus críticas a las autoridades y la élite gobernante, desde una perspectiva cercana a los intereses de artesanos y obreros calificados. Desde allí, desplegó una cruda ironía, estilo que sería adoptado por el resto de los periódicos de sátira que se refirieron a la problemática de los veteranos, especialmente en lo relativo a quienes resultaron mutilados producto de las heridas de guerra que recibieron. Su interés de denuncia también alcanzó a la problemática de los heridos en combate, acusando que la atención médica recibida por los lastimados en las batallas de Chorrillos y Miraflores era insuficiente, además de no recibir dinero para satisfacer sus necesidades básicas. Apuntó sus dardos contra el entonces presidente Pinto, espetándole que "A Usted no le importa eso, porque ya concluye su gobierno, y nada ha de avanzar con remediar las faltas de los que han dado lustre a su período presidencial". ${ }^{18}$

${ }^{18}$ Idem. 
Hacia mediados del año 1881, con la guerra entrampada en la instalación del gobierno provisional peruano de La Magdalena, las negociaciones de paz y el inicio de la Campańa de la Sierra, la situación vivida por muchos veteranos comenzó a ser más evidente. Juan Rafael Allende, en ese momento escribiendo en El Padre Cobos, protestó por la lentitud del gobierno para promulgar una ley de compensaciones, en vista de las apreturas económicas que sufrían muchos de los excombatientes. En la oportunidad, acusó que los miembros de los poderes ejecutivo y legislativo, estaban preocupados de las intrigas de la política palaciega en los pasillos de La Moneda y el Congreso, en vez de solucionar los problemas de los soldados y sus familias:

\footnotetext{
“¿Y el proyecto de ley de recompensa?

Duerme el sueńo de los justos.

Mientras tanto, gobierno y cámaras se dejan estar o politiquean sin tomar en cuenta que los días y semanas perdidos en fútiles discusiones de amor propio o de odios personales, son otros tantos pasos que hacen dar hacia la miseria, la desesperación o le crimen a los que, por ir a defender los sagrados intereses de la Patria, han quedado reducidos a desesperante situación”. ${ }^{19}$
}

Durantegran partede 1881, lacontingenciapolítica, entreellaslaintervención electoral por parte del poder ejecutivo, la asunción a la presidencia de la República de Domingo Santa María, las luchas por la secularización del Estado, el desarrollo de las negociaciones para finalizar con la guerra, la administración de la ocupación chilena del Perú y las alternativas de la campaña de la Sierra, monopolizaron el tenor de los escritos y caricaturas de El Padre Cobos. Empero, en mayo de 1882, volvió a la carga quejándose amargamente respecto de los alcances de la ley de recompensas para los veteranos de guerra, promulgada el 22 de diciembre de 1881, la cual para acceder a los beneficios les exigía inscribirse en la Oficina Calificadora de Servicios. ${ }^{20}$ En esa ocasión afirmó que la mencionada Ley era una mala broma para los veteranos, la cual se asemejaba a la que las madres les hacían a sus hijos "cuando, con un dulce en sus manos, les dicen: "Éste dulce será para el que no lo quiera." Los chicos se quedan mudos como una tapia o se limitan a balbucear entre dientes: "Yo no lo quiero". ${ }^{21}$

\footnotetext{
19 "Soldados o mendigos" En: El Padre Cobos, Santiago, Julio 5 de 1881.

${ }^{20}$ El Padre Cobos, Santiago, mayo 30 de 1882. Entre lo establecido en el cuerpo legal, se incluía el pago de pensiones por invalidez parcial o absoluta, además de la provisión de aparatos ortopédicos para intentar suplir los miembros mutilados de quienes los perdieron producto de las heridas recibidas. "Ley de recompensas por la campaña contra el Perú y Bolivia de 1881", En Méndez, Carlos. Héroes del silencio..., 112.

${ }^{21}$ "Nada, nada y nada", En: El Padre Cobos, Santiago, mayo 30 de 1882.
} 
En la misma línea, en octubre de 1882 recogió la molestia de muchos veteranos que debían superar la marańa burocrática del Estado para acceder a una compensación. En esta oportunidad, el blanco principal de su crítica fue la "Oficina de Tramitación”, departamento creado en marzo de ese año 1882, cuya tarea, en teoría, era facilitar la obtención de los beneficios, solucionar problemas y recibir los reclamos de los excombatientes. No obstante, según se desprende de los comentarios vertidos en el periódico, el servicio prestado en la repartición era deficiente:

“¿Hasta cuándo se hace chacota de la malhadada Ley de Recompensas? ¿Hasta cuándo los empleados encargados en el Ministerio de Guerra de tramitar los expedientes de los asignatarios ganan el sueldo perdiendo el tiempo y haciendo perder la paciencia a los deudos de los bravos en la última campaña?”. ${ }^{22}$

Con el transcurso de los meses la molestia de los veteranos aumentó y Allende colocó nuevamente el tema sobre el tapete. El año 1883 no fue distinto. En los últimos días de enero, sostuvo la necesidad de revisar la aplicación ley de compensaciones pues esta se estaba aplicando de manera incorrecta. ${ }^{23}$ Sumado a ello denunció que se estaban entregando pensiones a viudas de militares que provenían de familias influyentes, en desmedro de otras que, con mayor derecho por sus acciones y valor demostrado en batalla, como en los casos de Juan José San Martín, Ricardo Santa Cruz o Ramón Dardinagc. ${ }^{24}$ En un nuevo escrito, fechado en julio de 1883, sostuvo la necesidad de modificar la ley de recompensas, con el objeto que la mencionada Oficina de Tramitación no solamente funcionara en Santiago, sino también en las provincias. ${ }^{25}$

Algo similar ocurría con los pagos atrasados a los efectivos de los regimientos y batallones licenciados. Allende afirmó en El Padre Padilla, en octubre de 1884 con la guerra ya finalizada, que no se estaban liquidando lo que se les adeudaba a veteranos o familiares de soldados caídos que asistían a las dependencias del Ejército pues, en el erario castrense no existían los fondos suficientes para tal

\footnotetext{
22 "Hasta cuando", En: El Padre Cobos, Santiago, octubre 7 de 1882.

23 "Contador mayor", En: El Padre Cobos, Santiago, enero 27 de 1883.

24 "Pensiones merecidas, pensiones inmerecidas", En: El Padre Cobos, Santiago, junio 21 de 1883.

25 “Más fácil y más humano", En: El Padre Cobos, Santiago, julio 3 de 1883.
} 
efecto. Allí escribió:

"Todos los días estamos viendo que se licencia un cuerpo, se le suele pagar hasta la tropa, aunque mal y por mal cabo, la gratificación de los tres meses, se les da a jefes, oficiales y soldados las muchas gracias de cajón y...jabur, peseta! Soldados, oficiales y jefes piden que se ajusten sus atrasados haberes, los haberes de dos y más ańos; pero se les contesta invariablemente: "Hoy no se paga mañana si" ¿Y por qué no se paga hoy? "Porque el encargado de hacer los ajustes no ha presentado aún compaginadas sus cuentas". ${ }^{26}$

Un tópico especialmente importante para Allende, fueron las muertes y suicidios producidos entre excombatientes que no recibieron las compensaciones estipuladas en la ley. Las páginas de El Padre Cobos, consignaron el fallecimiento de un capitán de ejército antes que pudiera realizar los trámites necesarios para acogerse a los beneficios que le correspondían. ${ }^{27}$ Así también, informó respecto del suicidio del teniente de Guardias Cívicas Roberto Pradel. Luego de presentar un panegírico respecto del oficial, Allende aseguró que se trataba de una víctima de la injusticia del gobierno, pues otros militares sin valor alguno consiguieron ascensos solo por ser "favoritos" de los mandamases del gobierno:

"Ayer no más salían de aquí tenientes y subtenientes, de infantería unos, de artillería otros, y, sin haber sin olido la pólvora, los vemos hoy día pavoneándose por nuestras calles con cinco y más galones!! Siga el gobierno supremo su obra destructora y agregue esta nueva víctima de su desaparición al haber de su cuenta administrativa, que aquí liquidaremos". ${ }^{28}$

Así también, consignó el caso del capitán de Granaderos a Caballo José Luis Contreras, quien también habría terminado con su vida, producto de continuos vejámenes y postergaciones de las que era víctimas en las filas del Ejército. ${ }^{29}$

Por otra parte, Allende denunció una modificación a la ley de recompensas, la cual trajo como consecuencia la discriminación en la entrega de prótesis para los veteranosmutilados, dependiendodesugraduaciónenelescalafóndelEjército.Afirmó que a jefes y oficiales se concederían aparatos ortopédicos articulados, mientras que para suboficiales, clases y tropa, serían miembros fijos confeccionados en madera. ${ }^{30}$

\footnotetext{
26 “Tramposo!", En: El Padre Padilla, Santiago, octubre 28 de 1884.

${ }^{27}$ Era pobre!", En: El Padre Cobos, Santiago, agosto 22 de 1882.

28 "Una víctima de la Ingratitud", En: El Padre Cobos, Santiago, junio 13 de 1882.

29 “Otra víctima de don Domingo el Cruel”, En: El Padre Cobos, Santiago, agosto 19 de 1882.

30 "Ridícula economía", En: El Padre Cobos, Santiago, julio 12 de 1883.
} 
En ese contexto, Allende aprovechó los problemas que afectaban a los veteranos en otra dirección. En sus caricaturas y escritos dados a la luz en El Padre Cobos sumó a los excombatientes, mutilados, viudas y huérfanos de la Guerra del Pacífico con los sectores postergados de la sociedad chilena, caracterizándolos como un grupo opositor a las autoridades de gobierno y a sus políticas de administración del Estado. Así, en dos caricaturas los excombatientes y sus familias fueron sumados simbólicamente, a la campańa del periódico en contra del presidente Santa María y la Iglesia Católica. Más aún, en muchas de sus editoriales se desprendía que los verdaderos enemigos de Chile no eran el Perú y Bolivia, ya irremediablemente derrotados por las armas, sino la oligarquía y los especuladores al servicio del capital financiero. Allí acusó que compañías extranjeras deseaban hacerse de las riquezas salitreras conquistadas a sangre y fuego en la guerra, en circunstancias que en justicia los dueños debían ser todos los chilenos, en especial los excombatientes y los deudos de los caídos en combate. Por ejemplo, en la columna intitulada "Las salitreras del Toco", se queja por la propiedad de las salitreras, en manos de ingleses, en circunstancias que en manos de chilenos podrían entregar recursos suficientes para solucionar, por ejemplo, problemas como los de los veteranos, huérfanos y viudas de la guerra. ${ }^{31}$ Así, en "Obra de Verdugos!", se queja respecto de la posibilidad que la compañía francesa Dreyfus y Compañía, se hiciera cargo de toda la producción de salitre en Tarapacá. Así como, según Allende, sucedió con el cobre y el trigo, que ya en ese momento estaban en manos de capitalistas privados. ${ }^{32}$ En esa misma línea de análisis, en abril de 1883 afirmó: "Tenemos ya en Chile la oligarquía de los millones. Hasta el día todos nuestros gobiernos han gobernado con los banqueros, por los banqueros y para los banqueros". ${ }^{33}$

En definitiva, Allende escribía desde el desencanto, señalando que pese a la victoria militar obtenida en base a la movilización y sacrificio de los rotos, los beneficios económicos que trajo la conquista de Antofagasta y Tarapacá, eran disfrutados por capitalistas y oligarcas.

\footnotetext{
31 "Las salitreras del Toco", En: El Padre Cobos, Santiago, junio 24 de 1882.

32 "Obra de verdugos!", En: El Padre Cobos, Santiago, julio 11 de 1882.

33 "Vamos al feudalismo", En: El Padre Cobos, Santiago, abril 28 de 1883.
} 


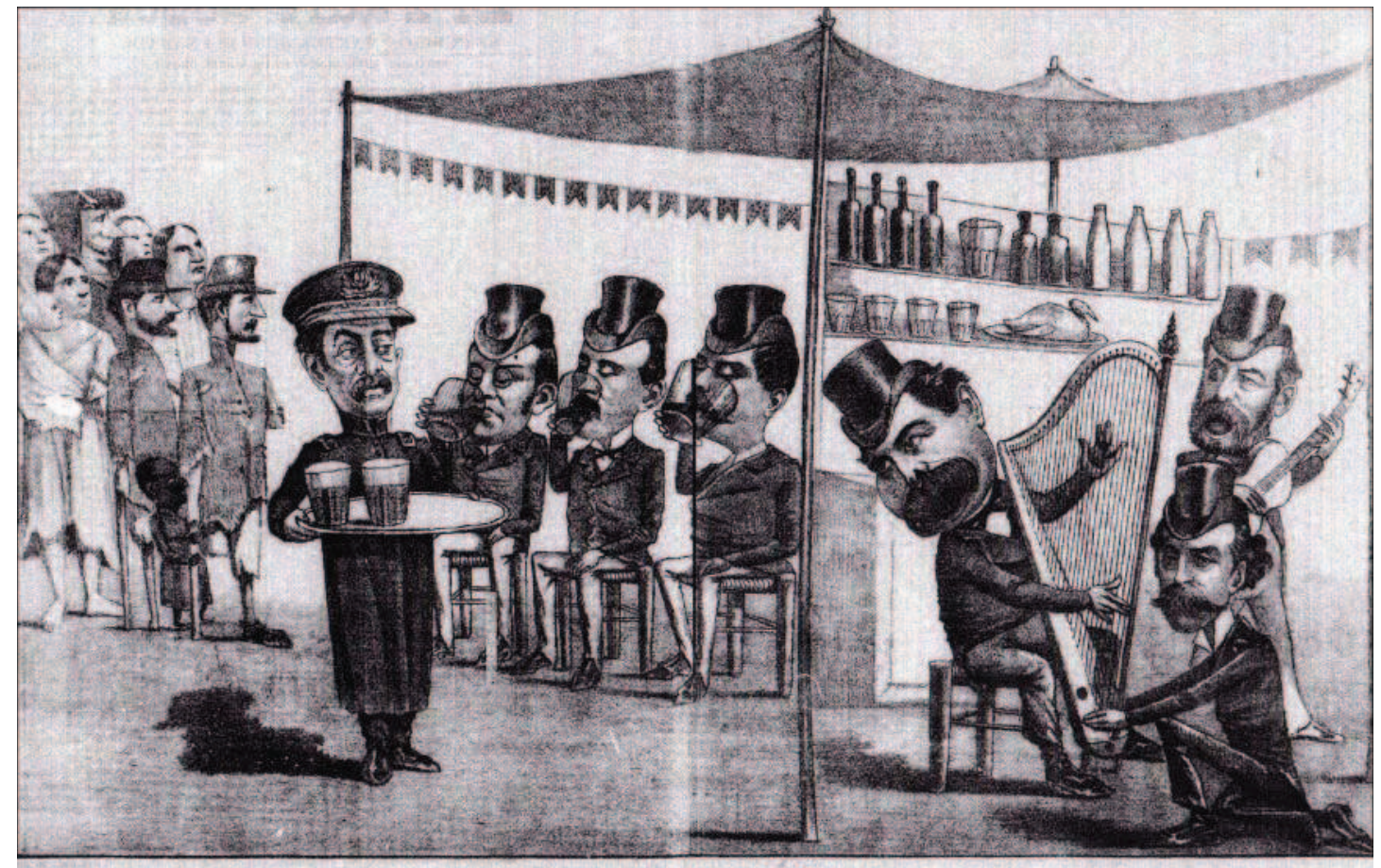

A cosillias del projimo.

Figura 4

Acorde a esa línea de interpretación de los hechos, el grabado intitulado "A costillas del prójimo", publicado el 27 de diciembre de 1882 en El Padre Cobos, muestra una fiesta donde el almirante Patricio Lynch, jefe de la ocupación chilena en Lima, aparece como un mozo sirviendo brebajes a señores de la alta sociedad. Cerca del oficial naval, Domingo Santa María, José Manuel Balmaceda y José Francisco Vergara se hacen cargo de la interpretación de la música. Por su parte, a la izquierda del dibujo, el Padre Cobos y el Negro (Personificación del periódico y su ayudante respectivamente), en compañía de algunos mutilados de la guerra, vestidos con restos de uniformes acompañados de sus mujeres e hijos, observan la escena alejados y sin participar de la algarabía. La caricatura responde a la idea de Allende, relativa a que los gobernantes y la clase política ponían atención a las necesidades e intereses de los poderosos, despreocupándose de la suerte de quienes pelearon y resultaron heridos en la guerra, quienes no podían llevar el sustento a sus casas. Así, los beneficios del esfuerzo de los soldados eran para otros (Figura 4). ${ }^{34}$

${ }^{34}$ El Padre Cobos, Santiago, diciembre 27 de 1882. 


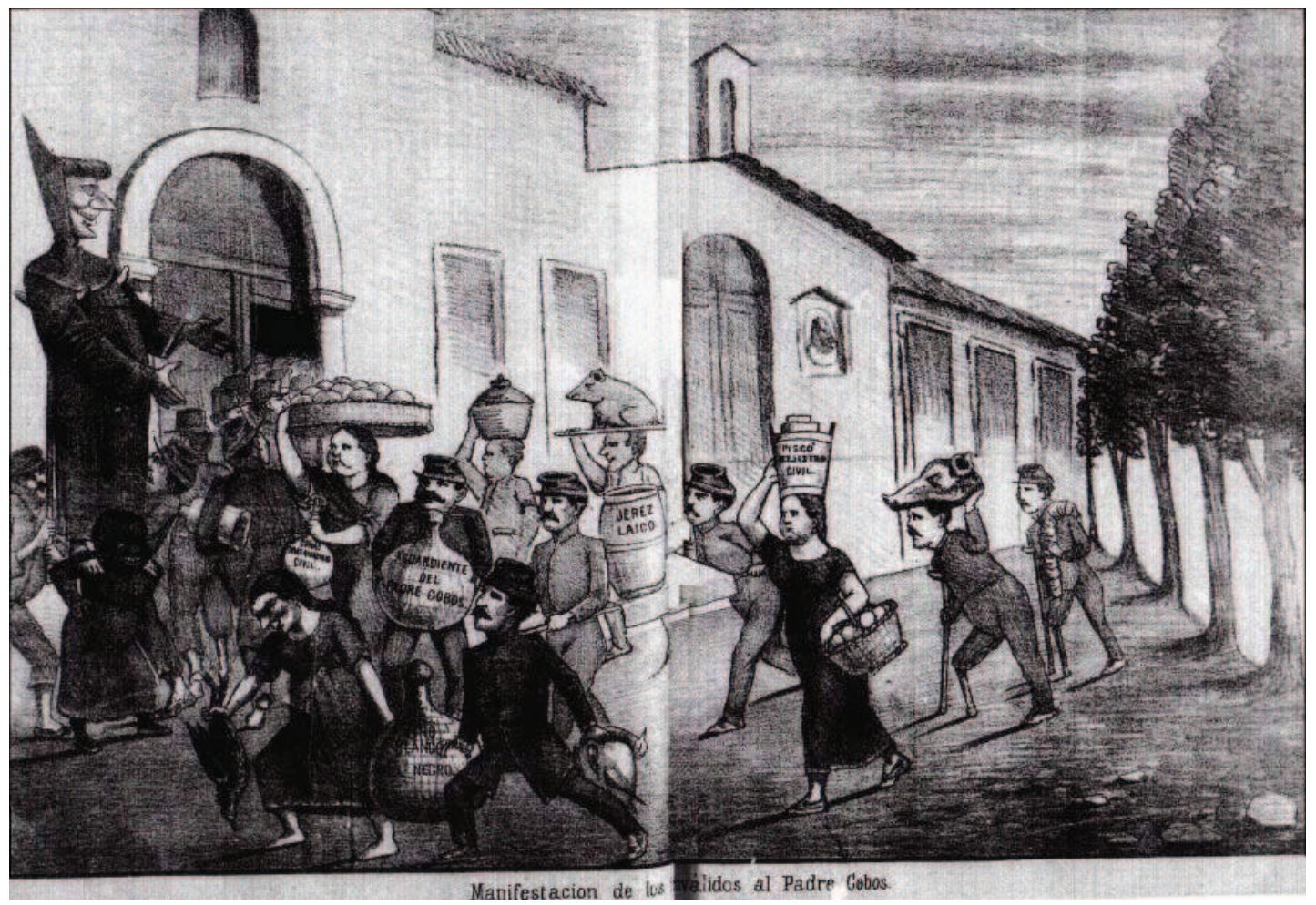

Figura 5

En la misma línea de interpretación, en otra caricatura los inválidos de la guerra expresan su gratitud al Padre Cobos participando de una fiesta a la cual llevan gran cantidad de comidaylicor. En el grabado, el dibujante mezcla dos temas de importancia para El Padre Cobos. En primer lugar, su preocupación por la suerte de los mutilados y luego su batalla por la laicización de la sociedad chilena del último cuarto del siglo XIX. Entre los aportes a la reunión se observan brebajes tales como "Coñac matrimonio civil", "Jerez laico" y "Pisco registro civil”. Además los asistentes al banquete portan dos bebidas alusivas al periódico: "Aguardiente del Padre Cobos" y "Vino blanco El Negro". El grabado se intitula "Manifestación de los inválidos al Padre Cobos" y fue publicado el 29 de junio de 1883, cuando la guerra se encontraba prácticamente terminada (Figura 5). ${ }^{35}$ Es aquí, donde con claridad se engarzan simbólicamente el "ideario político liberal” del último cuarto del siglo XIX en Chile, con la problemática de los veteranos.

${ }^{35}$ El Padre Cobos, Santiago, junio 29 de 1883. 

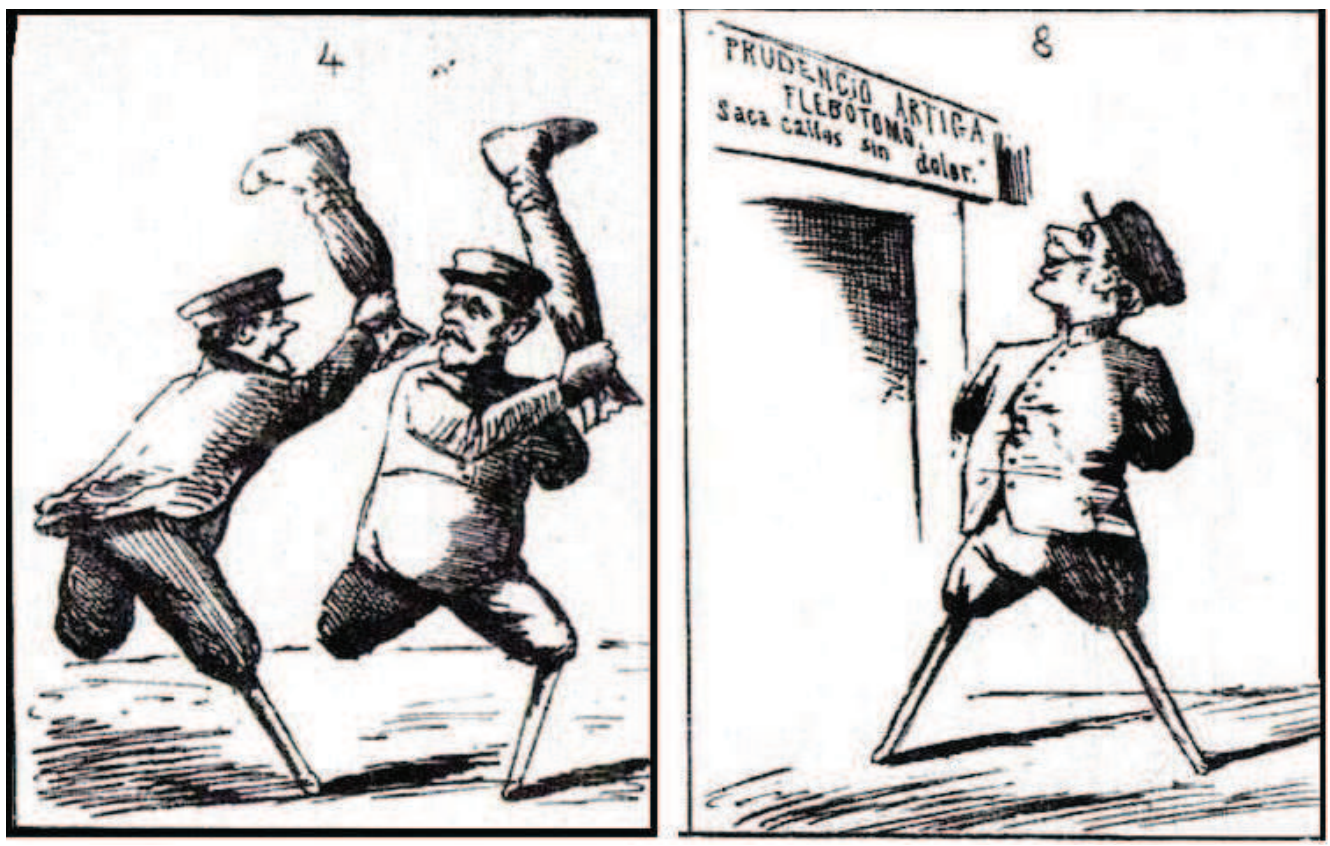

Figuras 6 y 7

Por su parte, El Padre Padilla, otra creación de Allende, incluyó en la edición del martes 23 de septiembre de 1884, ocho viñetas en la serie intitulada "Cosas de Inválidos" donde se muestran varias escenas donde se representan irónicamente las vicisitudes de la cotidianidad de los veteranos mutilados, que sufrieron en carne propia el rigor del conflicto. ${ }^{36}$ A continuación se reproducen dos de ellas, la número cuatro (Figura 6) y la ocho (Figura 7). La primera muestra una pelea de dos veteranos y es acompañado por el siguiente verso:

"Sin piernas, pero con brazos,

Dos recomendables cojos,

Pues no pueden a sablazos,

Casi se sacan los ojos

A piernazos i piernazos."

${ }^{36}$ El Padre Padilla, Santiago, septiembre 23 de 1884. 
La segunda reza:

“- Prudencio Artiga... Fleboto...

¡Vaya! Que nombre tan griego!

¿Dice que saca los callos

Sin dolor? Mucho me alegro!

Pues conmigo don Fleboto

Va a sacar... su macho a tiempo!"

En las postrimerías del conflicto al José Peluca, periódico de corte conservador y adversario político de El Padre Cobos, también hizo propia la causa de los veteranos.

Criticó ácidamente al presidente Santa María, responsabilizándolo por el estado de abandono en el que se encontraban los excombatientes:

"Si hemos de juzgar por lo que el gobierno ha hecho por las viudas, huérfanos y por el porvenir de nuestros valientes. Resta ver día a día por la calle el estado de miseria y de abandono en que se tiene a los inválidos de la guerra; esos heroicos mutilados". ${ }^{37}$

El Diógenes muestra una de "Las gangas de la guerra" en su edición del $1^{\circ}$ de agosto de 1884, ya con el conflicto en la práctica finalizado, pues a la sazón ya se había firmado el Tratado de Ancón con el Perú y pronto se protocolizaría el pacto de tregua con Bolivia. Un veterano que perdió ambas piernas las cuales fueron reemplazadas por prótesis de madera, comenta que una miniatura de soldado ha tenido menos fortuna que si mismo, pues él es entero de palo (Figura 8). ${ }^{38}$

\footnotetext{
37 "Los invencibles", En: José Peluca, Santiago, abril 26 de 1884.

${ }^{38}$ Diógenes, Santiago, agosto 1 de 1884.
} 

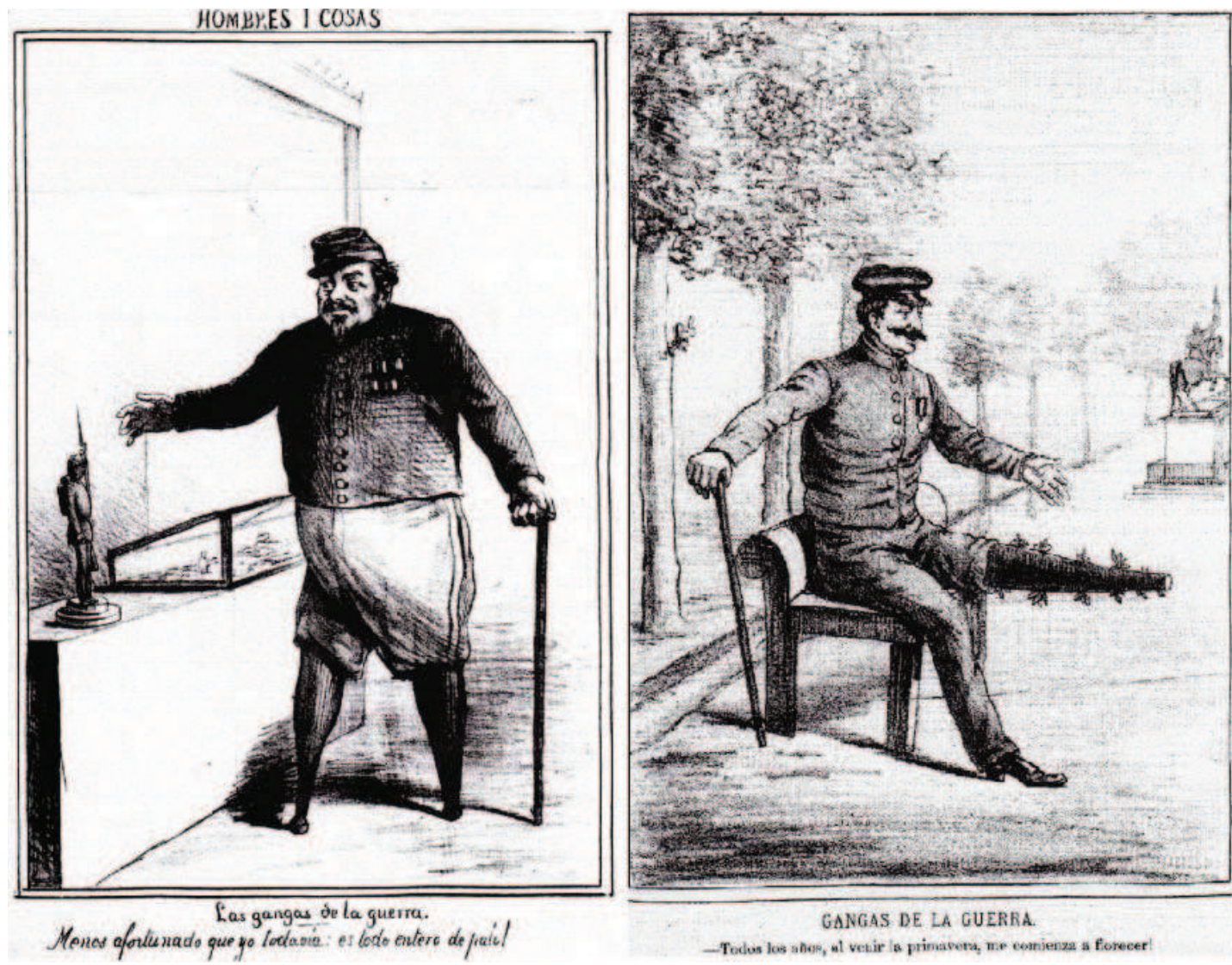

Figura 8 y 9

Otro ejemplo de incorrección política es el grabado visto también en el Diógenes el 3 de octubre de 1884, un veterano con su pierna izquierda mutilada portando un uniforme y medalla, sentado en un escaño de un parque donde a lo lejos se observa la estatua de algún prócer militar, se mofa de su prótesis de madera afirmando que ésta al llegar la primavera comienza a florecer al igual que el resto de la vegetación (Figura 9). ${ }^{39}$

Por último, la más acre de las críticas del Diógenes respecto de lo sucedido con los veteranos de guerra y el resto de los soldados movilizados. Muestra como un excombatiente en uniforme, portando algunas condecoraciones y cuyo brazoy pierna derecha le fueron amputados, lee atentamente el diario imponiéndose tardíamente

\footnotetext{
${ }^{39}$ Diógenes, Santiago, octubre 3 de 1884.
} 
de las razones por los cuales combatió y, más importante aún, porque su cuerpo fue mutilado transformándolo en un lisiado permanente. La leyenda de la imagen dice: "Terminada la guerra, el militar tiene derecho para leer en los diarios los motivos por que ha peleado". La caricatura salió de las prensas el 11 de junio de 1884 (Figura 10). ${ }^{40}$

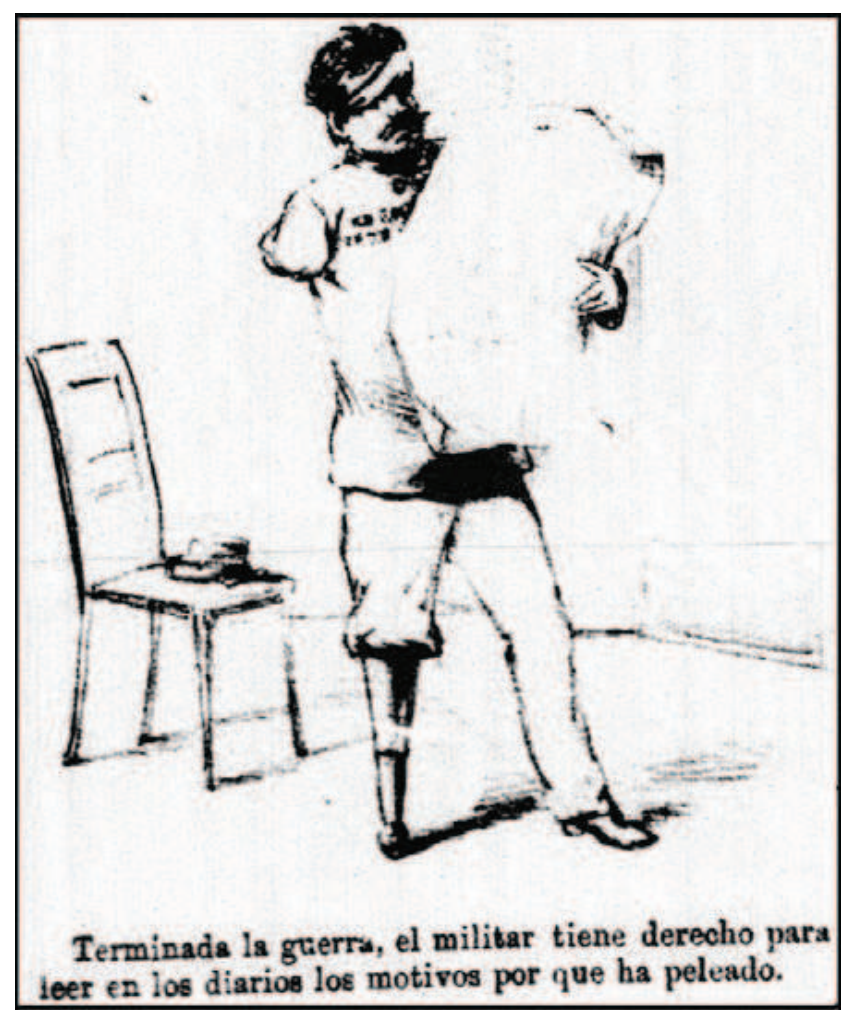

Figura 10

\section{REFLEXIONES FINALES}

Los artículos, versos y caricaturas publicadas en los periódicos satíricos chilenos durante la Guerra del Pacífico, mostraron la visión de sus creadores respecto de las diversas alternativas del conflicto, fueran estas diplomáticas, militares o de otra índole. Así, como parte de la opinión pública, los artistas y editores de los medios de prensa dedicados al humor de contingencia, participaron del debate producido en Chile a propósito del estallido, desarrollo y consecuencias del conflicto de 1879 .

\footnotetext{
${ }^{40}$ Diógenes, Santiago, junio 11 de 1884.
} 
Una vez lograda la conquista de Lima, los artículos, versos y caricaturas publicadas en los rotativos de humor político dedicadas a temáticas relativas a la guerra cedieron frente a las relacionadas con las disputas respecto de la elección presidencial de 1881, el conflicto entre Iglesia y Estado, entre otras temáticas. En la práctica, una vez que se consideró resuelto el conflicto, pese a iniciarse luego la Campaña de la Sierra, la discusión en la esfera pública se volcó hacia los temas relacionados con la administración interior.

Sin embargo, para los periódicos de sátira aún quedaba una batalla común. De manera transversal, diarios de distinta adscripción ideológica, fustigaron al gobierno y a la clase política, por no ser capaces de dar una solución integral a los problemas sufridos por quienes sirvieron en las filas del ejército y se vieron directamente afectados por el conflicto. Muchos veteranos, ilesos, heridos o mutilados, que tuvieron problemas para reinsertarse a la vida civil tras la vuelta de combatir en mar o en tierra. Esta causa, la quienes sufrieron en carne propia el rigor de la guerra y sus consecuencias, fue también la de editores de los rotativos satíricos chilenos. Ellos utilizaron el humor negro, la sorna, la ironía, la burla y la incorrección política, con el objeto de criticar y denunciar a las autoridades de los gobiernos de Aníbal Pinto y Domingo Santa María, los cuales en su interpretación, se revelaron como inoperantes para satisfacer las necesidades de los excombatientes y sus deudos. Caricaturistas y editores, no tuvieron inconveniente alguno en exponer sin tapujos las mutilaciones sufridas por los soldados desmovilizados. A juzgar por sus escritos y grabados, consideraron pertinente explotar la imagen del veterano discapacitado, aunque de esa manera pudiera menoscabar a los veteranos o a sus familias. En ese sentido, aprovecharon la libertad de expresión que gozaba la prensa del periodo, consagrada por la ley de imprenta de 1872, además de las posibilidades discursivas y recursos estéticos de la sátira, colocándolas al servicio de la causa de veteranos y mutilados, en pos de visibilizarla en la esfera pública de discusión respecto de la contingencia política chilena durante los años de guerra.

La idea fuerza del discurso desplegado en artículos, versos y caricaturas era la necesidad que el Estado y, en definitiva, la sociedad chilena premiara y se hiciera cargo apropiadamente de las necesidades de quienes arriesgaron su vida en pos de la victoria de la causa de Chile, en especial de los veteranos mutilados. Así también, cumplían su rol como censores y fiscalizadores de la acción del Estado 
y los gobernantes, propio de una sociedad con instituciones e ideario liberalrepublicano, como lo era la chilena durante el siglo XIX.

Así también, los problemas de los excombatientes, salpicaron las querellas relativas a la administración del Estado. La delgada línea entre la defensa de los intereses de los veteranos y la guerrilla ideológica fue traspuesta en una y otra dirección. Todo ello con un marcado tinte de desencanto, pues los beneficios de tras la victoria de las armas chilenas no eran aprovechados por quienes la hicieron posible. Juan Rafael Allende en El Padre Cobos, fue el principal exponente de aquella situación.

Los periódicos de sátira cuestionaron las políticas implementadas y el actuar de las autoridades respecto de los veteranos de guerra. Hicieron suya su causa y no cabe duda que a través de sus páginas, proporcionaron un estímulo para que la sociedad chilena, tomara conciencia de la situación por la cual atravesaron muchos de quienes empuñaron las armas en pos de la defensa de la causa chilena en la Guerra del Pacífico.

\section{REFERENCIAS}

\section{Periódicos}

El Ferrocarrilito, Santiago (1880-1881).

El Padre Cobos, Santiago (1881-1883).

El Corvo, Santiago (1881).

El Padre Padilla, Santiago (1884).

Diógenes, Santiago (1884).

José Peluca, Santiago (1884).

\section{Libros y artículos}

Anduiza, Eva. (coord.). Opinión pública y medioambiente. Monografías de educación ambiental. Barcelona: SBEA, SCEA, 2006.

Burke, Peter. Visto y no visto. El uso de la imagen como documento histórico. Barcelona: Crítica, 2001. 
Cid, Gabriel. "Un ícono funcional: la invención del roto como símbolo nacional. 1870 -1888”. En Gabriel Cid y Alejandro San Francisco (eds.). Nación y nacionalismo en Chile. Siglo XIX. Vol. I. Santiago de Chile: Centro de Estudios Bicentenario, 2009.

Cornejo, José Tomás. "La República como mujer en los periódicos de Juan Rafael Allende: un discurso político en caricaturas", Mapocho 59, Santiago, DIBAM, primer semestre 2006.

Crespi, Irving. El proceso de opinión pública. Barcelona: Ariel, 1997.

Cruz de Amenábar y Zaldívar, Trinidad. "El trazado fronterizo de la caricatura. Confrontación y cohesión en el proceso limítrofe chileno 1879-1902", Boletín de la Academia Chilena de la Historia 106 (1996): 122-158.

Donoso, Carlos y Couyoumdjan, Juan. "De soldado orgulloso a veterano indigente. La Guerra del Pacifico”. En Rafael Sagredo y Cristián Gazmuri (eds.). Historia de la vida privada en Chile. Tomo II. Santiago de Chile: Taurus, 2006.

González Bernaldo de Quirós, Pilar. "Literatura injuriosa y opinión pública en Santiago de Chile durante la primera mitad del siglo XIX”, Estudios Públicos 76, primavera de 1999.

Guerrero, Cristián. "Los capitanes de la industria a través de las caricaturas contemporáneas, 1870-1920", Cuadernos de Historia 16, 1996.

Home, David. Los huérfanos de la Guerra del Pacifico: El 'Asilo de la Patria', 18791885. Santiago de Chile: Centro de Investigaciones Diego Barros Arana de la Dirección de Bibliotecas, Archivos y Museos y LOM Ediciones, 2006.

Mc Evoy, Carmen. Guerreros civilizadores. Politica, sociedad y cultura en Chile durante la Guerra del Pacifico. Santiago de Chile: Ediciones Universidad Diego Portales, 2011. 
Méndez, Carlos. Desierto de esperanzas. De la gloria al abandono. Los veteranos chilenos y peruanos de la guerra del 79. Santiago de Chile: Centro de Estudios Bicentenario, 2009.

Héroes del silencio. Los veteranos de la Guerra del Pacifico (18841924). Santiago de Chile: Centro de Estudios Bicentenario, 2004.

Dolor y olvido. Los excombatientes bolivianos de la Guerra del Pacifico. Santiago de Chile: Centro de Estudios Bicentenario, 2013.

Rodríguez, Sergio. Problemática del soldado durante la Guerra del Pacifico. Santiago de Chile: Estado Mayor General del Ejército, 1985.

Rubilar, Mauricio. "Escritos por chilenos, para los chilenos y contra los peruanos: la prensa y el periodismo durante la Guerra del Pacífico (1879-1883)". En Carlos Donoso y Gonzalo Serrano (eds.). Chile y la Guerra del Pacifico. Santiago de Chile: Centro de Estudios Bicentenario, 2010.

Salinas, Maximiliano. "Erotismo, humor y trasgresión en la obra satírica de Juan Rafael Allende", Mapocho 57, primer semestre, 2005.

Salinas, Maximiliano; Palma, Daniel; Báez, Christián; Donoso, Marina. El que ríe último... caricaturas y poesías en la prensa humorística chilena del siglo XIX. Santiago de Chile: Centro de Investigaciones Barros Arana, 2001.

Sater, William. Chile and the War of the Pacific. Lincoln: University of Nebraska Press, 1986.

Zaldívar, Trinidad. "El papel de los monos. Breve crónica de un tercio de siglo de prensa de caricatura 1858-1891". En Ángel Soto (ed.). Entre tintas y plumas: historias de la prensa chilena del Siglo XIX. Santiago de Chile: Universidad de los Andes, Centro de Investigación de Medios Andes, CIMA, Facultad de Comunicación, 2004. 